\title{
THE EFFECTIVENESS OF USING INDEX CARD MATCH IN TEACHING VOCABULARY
}

\author{
Sri Ariani ${ }^{1)}$, Tri Setianingsih ${ }^{2)}$ \\ FPBS IKIP Mataram \\ sri_ariani@ikipmataram.ac.id ${ }^{1 \mathbf{1}}$, trisetianingsih@ikipmataram.ac.id ${ }^{2)}$
}

\begin{abstract}
This research aims to find out Is there any significant differences between the impact of traditional teaching method and using Index Card Match in teaching English vocabulary at the First Year Students of SMA HANG TUAH 3 MATARAM and to find out does using Index Card Match have a positive effect on students' vocabulary knowledge. The sample of this research is 40 students. The kind of this research is experimental research. The students are divided into two groups such as experimental group and control group. Then the research subjects are pre-tested to know their prior vocabulary mastery. After the treatment, the sample is post-tested to know their recent vocabulary mastery as the result of the treatment. The scores in both pre-test and post-test are taken as the main data of the research. The data is analyzed by using t-test.
\end{abstract}

Keywords: Index Card Match, Teaching, Vocabulary

\section{INTRODUCTION}

Without a sufficient understanding of words, students cannot understand others or express their own ideas. Vocabulary is important across the curriculum from language arts and social studies to mathematics and science. It is intimately connected to both effective reading and writing skills, and these skills in turn are necessary for doing well in school. The students need to master a lot of vocabulary list an educated native speaker will probably have a vocabulary of around 20.000 words. This is the result of adding about a thousand words a year to the 5.000 he or she had acquired by the age of five (Thornburry, 2002: 20). Moreover, to mastery vocabulary, students are able to know: (1) form of words so that know how is the words written, (2) position so that students know grammatical pattern words, (3) function of words, students are able to know when can use the word, (4) meaning, students be able to know what does to the word mean.
Assessment of vocabulary is critical for identifying children at risk for reading problems and for designing appropriate instruction. The use of oral measures is essential. Tests that require reading or writing make it impossible to differentiate other problems children may have, such as difficulties in word decoding or spelling, from lack of vocabulary knowledge. Learners with suspected learning disabilities should be individually assessed on measures that include both receptive and expressive oral vocabulary. Receptive vocabulary involves understanding of spoken words, for instance, asking a child to point to a picture that represents a word spoken by the examiner. Expressive vocabulary involves using or naming a word, as when the examiner shows a picture to a child and asks the child to name it. Although the relationship of receptive vocabulary to reading comprehension seems obvious, expressive vocabulary appears to be an even stronger predictor of beginning reading 
achievement than is receptive vocabulary. Therefore, both areas should be included in a comprehensive assessment

According to Thornbury, (2002: 62) learning wanting to find an appropriately idiomatic expression to express the general idea that teacher should be modern in their knowledge of teaching method would first look up or modern in the book's index.

Index card match is more active fun way to review the subject matter. It allows students to pair up and play a quiz with classmates. So that the students are paying attention and better enjoy the learning process because of this way with notes, learners are given the task of studying the topics that will be taught in advance, so that when they enter the classroom already has stock of knowledge.

This method is usually used to teach the words or sentences with a partner. For example, the word with the meaning, or about the answer, and so on. Methods can be said to be an exciting game because the students are challenged to find a suitable partner with (question and answer) involving physical.

The traditional (or conventional) teaching methods are teacher-centered and include the use of lectures and discussions while the problem solving element is presented by and/or discussed with the instructor; the syllabus, the teaching materials, and the student assessments are determined by the tutor and transmitted to students in various lectures (Cottel \& Millis, 1993). However, recent developments in accounting, such as the role of accountants in companies and organizations, the increased use of technology and the implementation of complex accounting practices have allowed a number of important changes in teaching (Williams, 1993).
Therefore, based on the researcher observation in SMA Hang Tuah 3 Mataram, the researchers have found that the students still weak in mastering vocabulary and often wrong in pronunciation because of less of the knowledge about the vocabulary itself. When the teacher asks any object or mention it in the class students could not answer it because students didn't understand with the questions conveyed by the teachers. Beside that, the problem often faced by students in learning English language is the way how to express their idea in real situation. It is become big problems for the students in arrange the sentences into good one because lack of vocabulary mastery.

Based on the explanation above, the researchers conducted research entitled: "the effectiveness of using index card match in teaching Vocabulary at the First Year Students of SMA Hang Tuah 3 Mataram.

\section{RESEARCH METHOD}

According to Hatch and Farhady, (1982: 1), Research is a systematic approach to finding answers to questions. The purposes of the research determine the method and the design of the research. In other to achieve the aims of the research, it is necessary to apply a suitable method among various kinds of method that can be used.

In this study, the researcher used quasi experimental with non-equivalent control group design. This study intended to know the effectiveness of "index card match" in teaching vocabulary.

One of the most commonly to use quasi-experimental designs in educational research can be represented as: 
Table 1. Research Design

\begin{tabular}{|l|c|c|}
\hline \multicolumn{1}{|c|}{ Sample } & $\begin{array}{c}\text { Experimenta } \\
\text { I Group }\end{array}$ & $\begin{array}{c}\text { Control } \\
\text { Group }\end{array}$ \\
\hline Pre-test & $\mathrm{O}_{1}$ & $\mathrm{O}_{2}$ \\
\hline Treatment & $\begin{array}{c}\text { Index Card } \\
\text { Match } \\
\text { Method }\end{array}$ & $\begin{array}{c}\text { Traditional } \\
\text { Teaching } \\
\text { Method }\end{array}$ \\
\hline Post-test & $\mathrm{O}_{3}$ & $\mathrm{O}_{4}$ \\
\hline
\end{tabular}

1. Experimental Group: The group, which is assigned to the experimental variable or treatment.

2. Control Group: The group that will allotted to controlled variable is termed as controlled group (Singh, 2006: 137).

\section{Procedure of Data Collections}

The procedure of collecting data in the chronological order as following:

\section{Pre-test}

In the process of collecting the data, the researcher came to the class as a teacher. The researcher gave the test for students before explaining the material. Pre-test is to identify the students' ability in vocabulary. The test was given to all of group, experimental and control group. It was intended to measure the ability of students in vocabulary before using "index card match".

\section{Post-test}

Before the researcher gave the students post-test, the researcher gave treatment to the experimental group. It was four meetings, two meetings for each class. After teaching process or treatment, the researcher gave post-test to both groups. The tests were similar with the pre-test, but different redaction. The tests included 25 items of written vocabulary.

\section{Technique of the Data Analysis}

After collected the data, the researcher analyzed them carefully. To find out the differences between the results of post-test of experimental and control group after giving the treatment. In this research the researchers used two steps in analyzing the data by using this formula:

$$
X=\frac{\sum x}{n}
$$

$\mathrm{X} \quad=$ the symbol we use for mean

$\sum \quad=$ symbol for summation

$X_{1} \quad=$ value of the item $\mathrm{xi}=1,2 \ldots$

$\mathrm{N}=$ total number of items.

(Dowdy, 2004: 271)

Inferential analysis is concerned with the various tests of significance for testing hypotheses in order to determine with what validity data can be said to indicate some conclusion or conclusions. It is also concerned with the estimation of population values. It is mainly on the basis of inferential analysis that the task of interpretation (i.e., the task of drawing inferences and conclusions) is performed

$$
\mathrm{t}=\frac{M x-M y}{\sqrt{\left(\frac{\sum x^{2}+\sum y^{2}}{N x+N y-2}\right)\left(\frac{1}{N x}+\frac{1}{N y}\right)}}
$$

Where:

Mx = The mean score of experimental group

My = The mean score of control group

$\mathrm{X}^{2}=$ The square deviation of experimental group

$\mathrm{Y}^{2}=$ The square deviation of experimental group

$\mathrm{Nx} \quad=$ The sample of experimental group

$\mathrm{Ny}=$ The sample of control group

$\sum \quad=$ The sum of

$2=$ Degree of freedom

(Kothari, 2004:209) 
The formula above came to computation of comparing coefficient of the two mean score (experimental and control group), whether it is significant or not. Testing hypothesis was used to find out the effect of Index Card Match in teaching vocabulary. It was revealed that from the calculation above there was significant different between the result of pre-test and post-test both of groups, the researcher used inferential analysis by using t-test formula of comparison between the result of t-test and the value of t-table above.

like the control group, the mean of experimental group ${ }^{\text {ee }} \mathrm{s}$ posttest scores (56.55) is larger than the mean of pretest scores (36.00). Therefore, from these numbers can conclude on the average the way of teaching has caused the improvement of students ${ }^{\text {ee }}$ scores in both relevant groups.

As Table 1and 2 show the mean of the two groups is similar in pre-test, but the mean of the two groups was different in post-test. The result of pretest showed that the two groups were almost at the same level of vocabulary knowledge and the mean of two groups were not of great difference.

After giving treatment (vocabulary index card match) to the experimental group and traditional teaching method to the control group, the research questions of the study were to be answered "Is there any significant differences between the impact of traditional teaching method and using Index Card Match in teaching English vocabulary at the First Year Students of SMA Hang Tuah 3 Mataram? Does using Index Card Match have a positive effect on students' vocabulary knowledge? to answer these questions, the researcher used two comparisons.
First, the performances of the two groups compared and second the performances of the two groups in the pretest and post-test compared to investigate their progress and the influence of using index card match and traditional teaching method treatment. The posttest results show that there is a significant difference between the control and the experimental group regarding their vocabulary knowledge.

The $t$ observed is 7.34 and $t$ critical at our selected significance level of 0.05 for degree of freedom 20 is 2.086 .

The $\mathrm{t}$ observed exceeds the $\mathrm{t}$-critical implying that the experimental group performed significantly better in the posttest. As Table shows the posttest results reject the first null hypothesis and it was concluded that there is a significant difference between the experimental and the control group in terms of their vocabulary.

Based on the result of data analyzed, index card match has positive effect in teaching vocabulary, because the mean score of experimental group was higher than the control group $(\mathrm{Mx}=20.55>\mathrm{My}=$ 12.1)

\section{FINDING AND DISCUSSION}

Using vocabulary index card match card facilitates the students involvement in the class work by sharing answers, trying to participate, paying attention, giving the examples, encouraging to take part in the lesson, participating as volunteers, interacting with each other in a low-risk, warm-up activity, utilizing the new words in the example, working on the vocabulary and pronunciation. The findings revealed that participants in the experimental group, who had received the treatments on vocabulary index card match, significantly 
enhanced better performance in a vocabulary test. The result of this study indicated that there was significant difference in the efficiency of vocabulary index card match compared to traditional teaching method. It was confirmed that learning vocabulary index card match would lead to better learning than traditional method for four main reasons. According to Thornbury, (2002: 62) learning wanting to find an appropriately idiomatic expression to express the general idea that teacher should be modern in their knowledge of teaching method would first look up or modern in the book's index. New words can easily be practiced extensively with vocabulary index card match. Learners can separate cards into several categories based on their difficulty level. It helps them review difficult words more frequently than easy ones. Second, working with flash card increases vocabulary retrieval.

\section{CONCLUSION AND SUGGESTION}

Through the analysis of the findings gotten from the studentse vocabulary pretests and posttests, it was concluded that the contribution of vocabulary flash card in teaching vocabulary to students led to a higher level of vocabulary improvement. Using vocabulary flash card facilitates their involvement in the class work by sharing answers, trying to participate, paying attention, giving the examples, encouraging to take part in the lesson, participating as volunteers, interacting with each other in a low-risk, warm-up activity, utilizing the new words in the example, working on the vocabulary and pronunciation.

The findings revealed that participants in the experimental group, who had received the treatments on vocabulary index card match, significantly enhanced better performance in a vocabulary test. Therefore, consequently, through rejecting the first and second null hypothesis, the researcher can claim that vocabulary index card match is a useful way of enhancing vocabulary learning and can play an important role in teaching and learning vocabulary to the First Year Students of SMA Hang Tuah 3 Mataram.

The researcher should give some suggestion related to the finding of the study. The researcher expects that there search was beings useful for English teacher, the students, and the researcher.

1. To English teacher

since vocabulary is a very important part of the language, a teacher must equip himself/herself with up-to-date techniques and methods of teaching them. So, the results of this research can be valuable for language teachers at the level of middle school, high school, preuniversity, and universities.

2. To the students

the present study showed a new technique in vocabulary learning and teaching such as seven-step vocabulary Index card match in order to facilitate vocabulary learning for students and also provide an opportunity for them to use or review their vocabulary in every situation. The students became more confident in their own abilities, and they can motivate themselves to resolve the difficult situation because they have high motivation.

3. To the next researcher

The researcher hoped that other researchers had to find a more effective strategy for making motivation of students increased. 


\section{REFERENCES}

Allen, Virginia French. (1983). Techniques in Teaching Vocabulary. Oxford: Oxford University Press.

Cottel, P.G., \& Millis, B.J. (1993). Cooperative structures in the instruction of accounting. Issues in Accounting Education, 8(1), 40-60.

Dowdy, Shierly., Stanley, Weardean., \& Daniel Chilko. (2004). Statistics For Research Third Edition. Canada: A John Wiley \& Sons, Inc. Publication.

Hatch, Evelyn., and Hossein, Farhady. (1982). Research Design and Statistics for Applied Linguistics. Los Angeles: University of California.
Kothari, C. R. (2004). Research Methodology: Methods \& Techniques. New Delhi: New Age International (P) Limited, Publishers. Singh, Kumar. (2006). Fundamental of Research Methodology and Statistics. New Delhi: New Age International (P) Ltd., Publishers.

Suprijono, Agus. (2013). Cooperative Learning Teory \& Aplikasi PAIKEM. Yogyakarta: PustakaPelajar.

Thornburry. (2002). How to Teach Vocabulary. London: Pearson Education Limited.

Williams, D.Z. (1993). Reforming accounting education. Journal of Accountancy, 176(2), 76-82. 